\title{
Recent landslide studies in the Dolomites (Eastern Italian Alps) for hazard assessment and mitigation
}

\author{
F. Mantovani', A. Pasuto ${ }^{2}$, and S. Silvano ${ }^{2}$ \\ 'Department of Geological and Palaeontological Sciences, University of Ferrara, \\ Corso Ercole I I d'Este n ${ }^{\circ} 32, I$ - 44100 Ferrara, Italy \\ ${ }^{2}$ CNR-IRPI, National Research Council, Research Institute for Hydrological and Geological \\ Hazard Prevention, C.so Stati Uniti $n^{\circ} 4$, I - 35127 Padova, Italy
}

\begin{abstract}
The correct interpretation of landslide hazard, and consequently the optimisation of the interventions to be carried out in order to mitigate the loss of human lives and economic assets, depends on some general considerations. Firstly, gravitational phenomena should be regarded as an effect of natural landscape evolution, and secondly, the interaction of these phenomena with human activities and structures causes casualties and damage. Indeed, the population growth has led to greater needs for space and natural resources. On the other hand, the constant technological progress and improvement of living standards have caused remarkable changes in natural environment. Consequently, the events such as landslides have had increasingly serious consequences on human life and activities.

The Eastern Italian Alps, and in particular the Dolomites, are famous mountainous areas for their well-organised winter and summer resorts located at different elevations along the slopes and in the valleys. The territory includes high (more than $3,000 \mathrm{~m}$ ) peaks alternating with densely populated valleys. Most of the villages are located on alluvial fans, at the bottom of the valley, or on the toe of ancient landslide accumulations. This fact implies a high degree of risk for civil populations, urban settlements, and infrastructure. The Dolomites are prone to sliding owing to their steep slopes and unfavourable structural setting (i.e., an intensely faulted and jointed sequence of rigid and plastic formations). In this framework, the paper describes some experience of landslide investigations and monitoring carried out in this area.
\end{abstract}

\section{INTRODUCTION}

The Eastern Italian Alps, and in particular the Dolomites, are well-known for their winter and summer mountain resorts located at different elevations as well as in the valleys. The territory includes high peaks (over 3,000 m) alternating with densely populated valleys. The Dolomites are prone to sliding because of either high slope angles or the predominant structural setting, which is made up of sequences of rigid and ductile formations characterised by intense faulting and jointing. In this context, the assessment of hazard resulting from gravitational phenomena becomes particularly important also for correct territorial planning and safety of population. This paper intends to provide some general remarks on landslide hazard, and to describe two cases of landslide investigation and monitoring from the Eastern Italian Alps.

\section{LANDSLIDE HAZARD}

It may be stated that landslide hazard is generally neglected, as more emphasis is given to other types, such as seismic and volcanic hazards. The fact that landslide hazard is usually underestimated is even more unfortunate, since slope movements are usually more easily predictable and manageable than earthquakes, volcanic eruptions, or hurricanes. Besides large-scale mass movements (which occur quite seldom), there are a huge number of medium- to small-scale landslides, which are so widespread that the related cost is even higher than that of catastrophic events.
The losses due to low-magnitude, high-frequency events are also generally increasing, especially in developing countries, because of human activity, which tends to increase landslide hazard (on road cuts, quarries, etc.) as well as vulnerability.

The correct interpretation of landslide hazard, and consequently the optimisation of the interventions to be carried out in order to mitigate the loss of human lives and economic assets, depends on some general considerations. Firstly, gravitational phenomena should be considered as an effect of natural landscape evolution, and secondly, the interaction of these phenomena with human activities and structures causes casualties and damage. Indeed, the rapid population growth has imposed a greater need for natural resources and space available for human activities and, on the other hand, constant technological progress and the improvement of living standards have led to remarkable changes in the natural environment. Consequently, natural events such as landslides are leading to serious consequences on human life and activity.

Landslide hazard refers to the probability that a landslide of a certain magnitude takes place in a particular time interval and in a specific area (Brabb 1984; Hansen 1984; Hartlén and Viberg 1988; Hutchinson 1995; Jones 1992; Kienholz 1984; Panizza 1987; Pasuto and Soldati 1996; Varnes 1984; Wu et al. 1996). Usually, the main goal hazard assessment is to produce maps able to classify all existing landslides and to delimit the areas presently stable by rating them with various degrees of landslide susceptibility, assessed on the basis of 


\section{F. Mantovani et al.}

geological, geomorphological, morphometric, and geotechnical aspects (Meijerink 1988).

In recent years, the use of Geographic Information System (GIS) was shown to be particularly fruitful in assessing landslide hazard (Carrara et al. 1991; Carrara and Guzzetti 1995), especially since it is possible to undertake the study on different scales, each scale requiring its own input maps and mapping unit attributes. For landslide hazard assessment on a detailed site investigation scale, absolute or numerical methods are increasingly utilised. Such methods, based on a deterministic approach, express landslide hazard, through stability modelling, in terms of safety factor or of probability that a certain event might take place. The required input data are: depth of the slip surface, soil strength parameters, slope angle, and pore water pressure.

However, it must be emphasised that the quality of GIS analysis and modelling is always strictly connected with the precision and number of input data for each parameter considered. Therefore, even if extremely powerful computer software is available, the reliability of landslide hazard assessment depends very much on the experience and ability of the scientists and technicians to carry out archive data analysis, remote sensing, ground survey, mapping, and monitoring.

Therefore, the assessment of landslide hazard should be based on a precise knowledge of landslide phenomena, in terms of type, mechanism, and evolution characteristics as well as the main factors controlling their temporal and spatial development. The detailed investigation (including systematic monitoring of the main parameters influencing slope stability) is required for mitigating the effects of these events. A need was therefore felt for better defining and quantifying these parameters, in order to develop effective models of landslide development, which would permit more accurate forecasting of the kinematics of unstable soil and rock masses.

\section{GEOLOGY AND GEOMORPHOLOGY OF THE STUDY AREA}

The Italian Dolomites (Fig. 1) include some high mountains such as Mt. Marmolada (3,343 m), Mt. Antelao $(3,263 \mathrm{~m})$, and Mt. Civetta $(3,220 \mathrm{~m})$, surrounded by densely populated areas (such as Cortina d'Ampezzo). The Dolomites belong mostly to the structural units of the Southern Alps and, to a lesser extent, to the External Dinarides. Three major facies may be distinguished: 1) igneous and metamorphic sequence (composed of intrusive, volcanic, and metamorphic rocks of variable age, from pre-Hercynian up to Tertiary); 2) a sequence of non-metamorphic rocks of Palaeozoic age; and 3) a sedimentary unit of Permian to Quaternary age (with the Triassic-Cretaceous carbonate platform deposits, Lower Cretaceous-Palaeogene flysch, Palaeogene carbonates, and Oligo-Miocene molasses).

The tectonic history recorded not only deformations related to the Alpine compressional phases, but also many synsedimentary events since the post-Hercynian rifting. During the Tertiary, two main compressional phases deformed the Dolomites. During the pre-Miocene phase (Upper Oligocene-Lower Miocene), when the Dolomites were still below sea level, only the sedimentary cover was involved in development of the NNW-SSE- and NW-SE-trending thrusts and fold axes, and $\mathrm{N} 20^{\circ}$ dextral strike-slip faults related to the ENE-WSW compression (Siorpaes 1991). The S-ESE-verging Neo-Alpine phase (Neogene) involved also the basement in the deformation. The major structural features of this phase are S-verging thrusts in connection with NW-SE- and NNE-SSW-trending strike faults and a set of wide and gentle ENE-WSW-trending synclines.

The landforms are the result of the complex geomorphological evolution, particularly intense since the end of the Würmian glaciation, and are at the same time closely connected with the tectonic history of the region and its predominant structural setting, which is characterised by an alternation of rigid and ductile formations. The plastic rock types generally crop out in the lower parts of the mountain slopes giving rise to a flat morphology and a widespread hummocky topography. The rigid rock types, which overlie the plastic ones, are made up of dolomites and limestones. The alternating stiff and plastic rock sequences make the area particularly prone to sliding.

During the Last Glaciation, the morphology of the whole area was strongly modified by glacial erosion processes, which have deepened and enlarged the valleys. The Postglacial period, during which the glaciers underwent a reduction in size following significant climate change, was characterised by huge mass movements, which affected the hydrographic network of the region. Depending on the susceptibility to erosion of the rock types that constitute the watersheds, in some places, the streams give rise to disastrous debris flows. Most of the villages are located on alluvial fans, in the valleys, or on the toe of ancient landslide accumulations. This setting implies that the villages are prone to serious damage whenever there are critical floods, landslide reactivations, and debris flows.

The climatic conditions of the area are typical of a high mountain setting, characterised by two distinct seasons during which the temperature remains below $0^{\circ} \mathrm{C}$ and above $0^{\circ} \mathrm{C}$, respectively. Two peaks of rainfall can be observed in late spring and autumn. Especially during the summer, the intensity of some rainfall events can reach $50 \mathrm{~mm}$ per hour and rapid mass movements may occur. The annual mean rainfall reaches $1,200 \mathrm{~mm}$, whereas the total precipitation can exceed 1,600 mm. Maximum snowfall occurs mainly in January and February, and the daily mean value of temperature remains below $0^{\circ} \mathrm{C}$ from December to March.

\section{CASE STUDIES}

Two case studies (Fig. 1) from the Dolomites are described below. They exhibit various types of landslide related to the diverse geological, geomorphological, and structural 


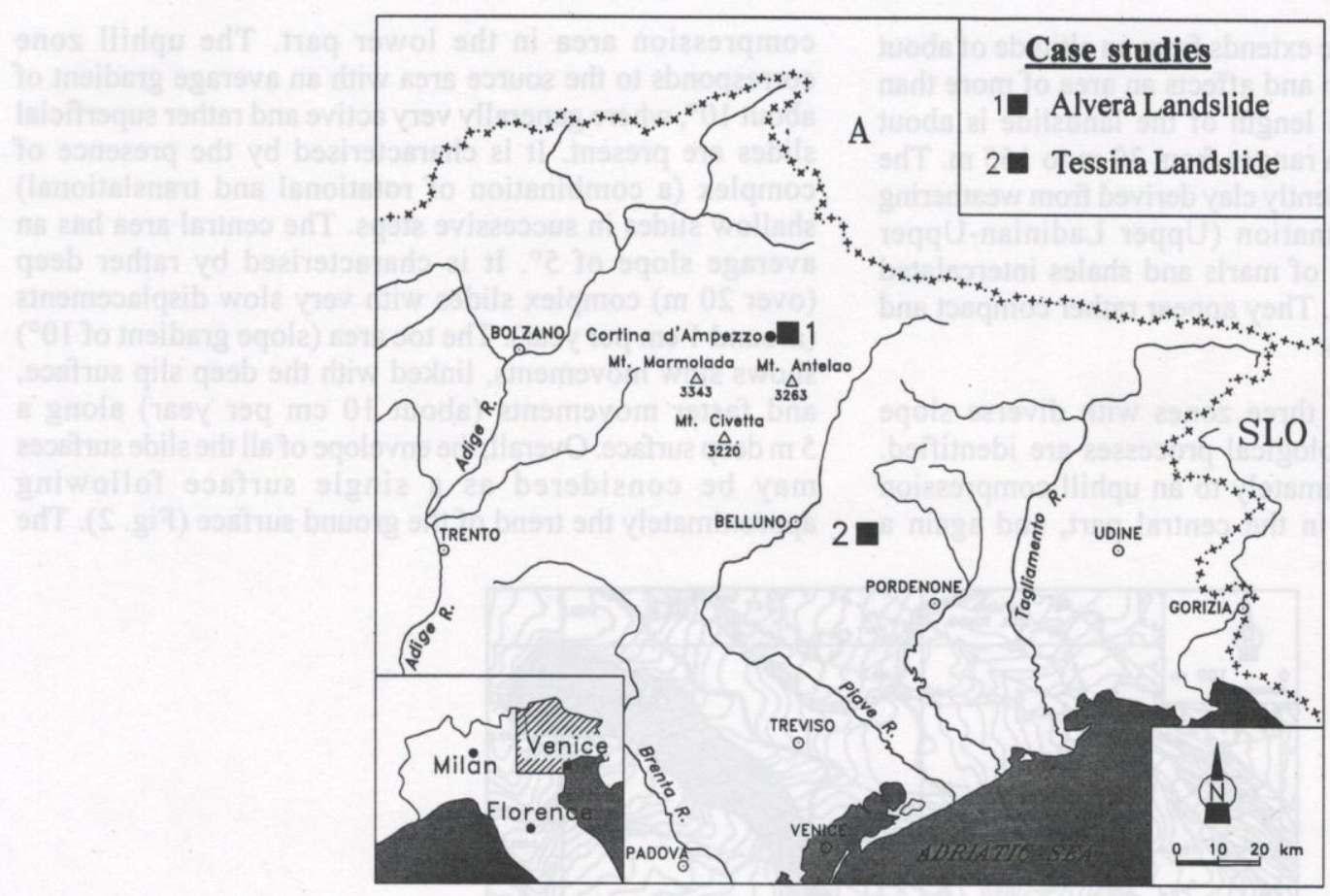

Fig. 1: Location map of the study areas.

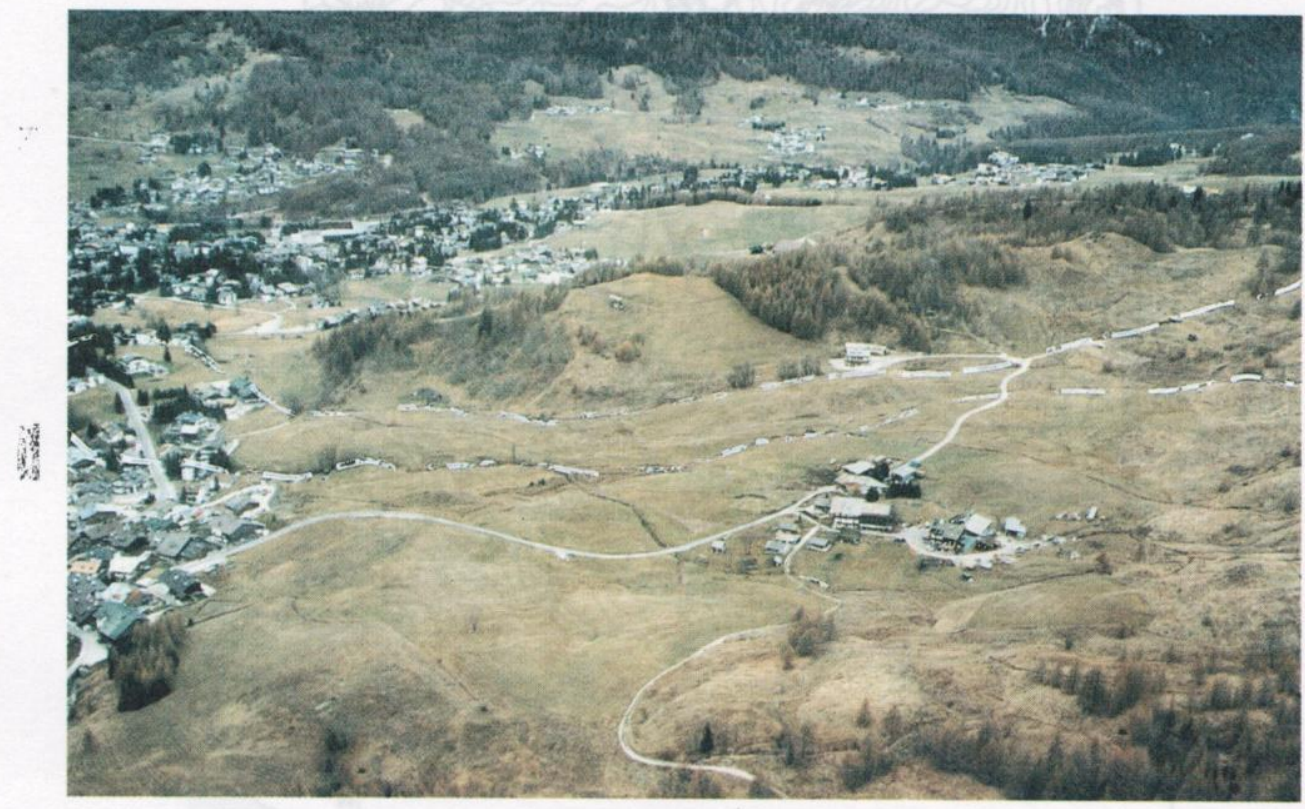

Plate 1: Aerial view of the mid-lower part of the Alverà Landslide. The boundary of the landslide is reported.

characteristics as well as the particular risk conditions. An effort was made to solve these problems by carrying out various types of investigation and implementing specific control measures.

\section{The Alverà Landslide}

The Alverà Landslide, located in the proximity of Cortina d'Ampezzo, is a rather elongated and active earth flow ("mudslide" according to Brunsden 1984) involving reworked clayey material coming from the alteration and weathering of the rocks belonging to the S. Cassiano Formation, which widely crops out all over the area (Plate 1). Since the study area is characterised by its high environmental and economic values as well as intense urban development, this landslide was monitored for obtaining the kinematic and hydrogeological parameters. Various types of information collected on the evolution mechanism of this landslide during the past ten years were used in a numerical model for an accurate prediction of the ongoing instability processes.

\section{Morphological details}

The Alverà Landslide is located on the southern slope of Mt. Pomagagnon, which lies in the east of Cortina 


\section{F. Mantovani et al.}

d'Ampezzo. The landslide extends from an altitude of about $1,500 \mathrm{~m}$ down to $1,300 \mathrm{~m}$ and affects an area of more than 18 ha (Fig. 2). The total length of the landslide is about $1.7 \mathrm{~km}$, whereas its width ranges from $30 \mathrm{~m}$ to $165 \mathrm{~m}$. The material involved is prevalently clay derived from weathering of the S. Cassiano Formation (Upper Ladinian-Upper Carnian), which consists of marls and shales intercalated with grey biocalcarenites. They appear rather compact and without any stratification.

Geomorphologically, three zones with diverse slope gradients and geomorphological processes are identified. They correspond approximately to an uphill compression area, an extension area in the central part, and again a compression area in the lower part. The uphill zone corresponds to the source area with an average gradient of about $10^{\circ}$, where generally very active and rather superficial slides are present. It is characterised by the presence of complex (a combination of rotational and translational) shallow slides in successive steps. The central area has an average slope of $5^{\circ}$. It is characterised by rather deep (over $20 \mathrm{~m}$ ) complex slides with very slow displacements (around $1 \mathrm{~cm}$ per year). The toe area (slope gradient of $10^{\circ}$ ) shows slow movements, linked with the deep slip surface, and faster movements (about $10 \mathrm{~cm}$ per year) along a $5 \mathrm{~m}$ deep surface. Overall, the envelope of all the slide surfaces may be considered as a single surface following approximately the trend of the ground surface (Fig. 2). The
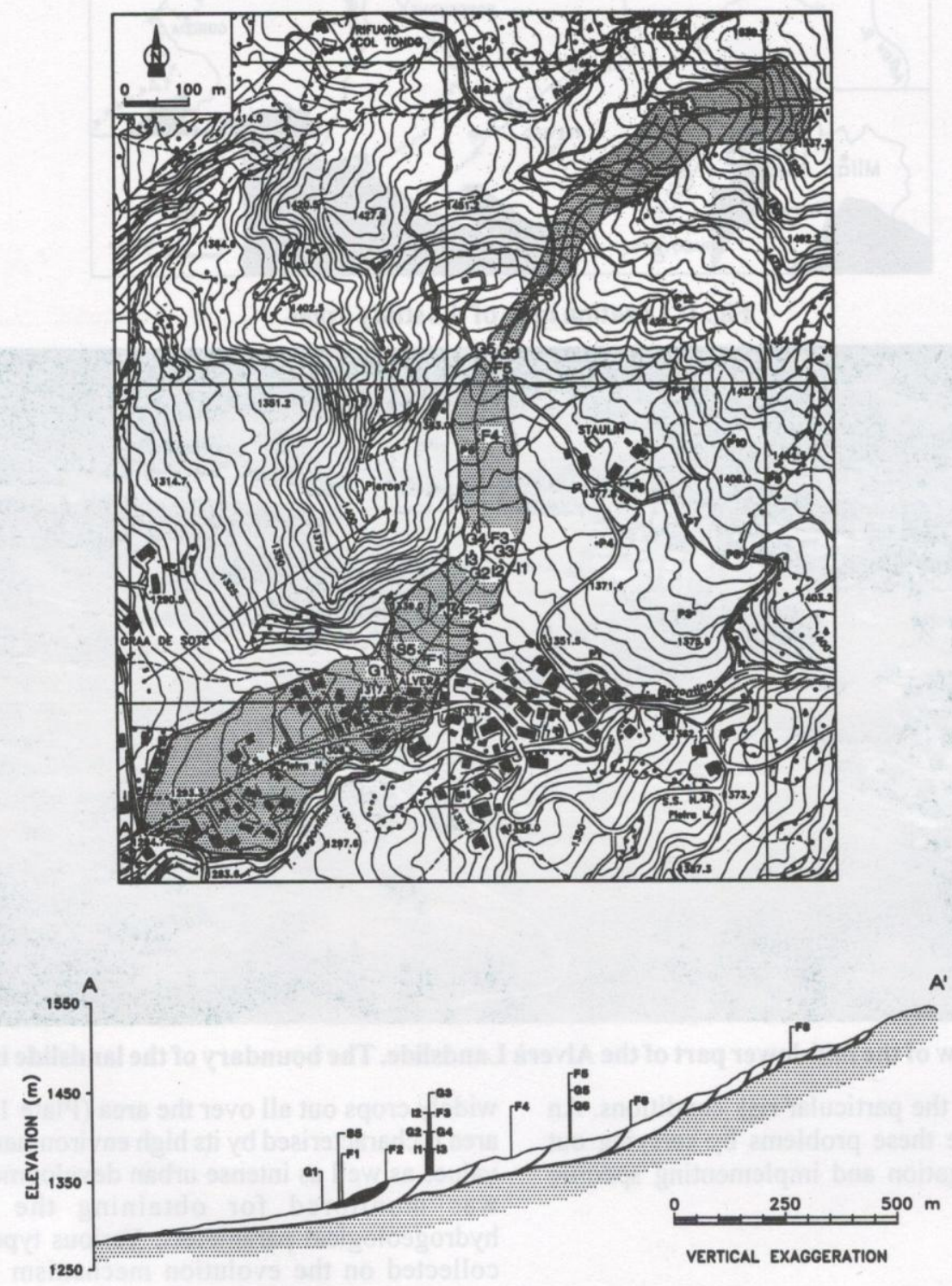

Fig. 2: Location of the instrumentation and schematic longitudinal section of the Alverà Landslide (in white the main landslide body, affecting the weathered clays of the S. Cassiano Formation; in black the most superficial and active landslide): P- topographic bench marks; F-open standpipe piezometers: I, G and S-inclinometers (after Angeli et al. 1999). 
thickness of the whole body tends to decrease towards the top of the slope, where the unstable mass is extremely dismembered and subdivided into depressions and uphilldipping slopes, owing to the presence of several wide cracks.

After comparing all the geomorphological observations and investigations carried out since 1989 on this landslide, it was possible to define in detail the geometry of the various blocks making up the landslide body. It was also possible to make a clear distinction between the main landslide body with thickness of 18-25 m and a secondary slab-type body ( $5 \mathrm{~m}$ thick) overlapping the main one in the lower part. As the latter is sufficiently long, it may be considered as an infinite surface.

\section{Past events and style of activity}

Within the framework of EU-funded projects, investigations on the relationships between landslide occurrence and climate change from the Late Glacial times were carried out in the area of Cortina d'Ampezzo. For this purpose, radiocarbon dating of several mass movements was also done. With respect to the Alverà Landslide, these dates show recurrent activities since the retreat of the Würmian Glaciers (Panizza et al. 1996, 1997; Pasuto et al. 1997). In fact, dated organic finds, in some way correlated with the periods of intense landslide activity, have produced the following non-calibrated ages: $8710 \pm 70,4350 \pm 60,3315 \pm 40,2810 \pm 60$, $2560 \pm 80$, and $1460 \pm 30 \mathrm{yr} \mathrm{BP}$.

This continuous activity seems to have lasted also in historical times. Since 1879 , the archive data contain records of repeated movements of the landslide. The most dangerous reactivations occurred in $1879,1924,1927,1935$, and 1942 when some houses had to be evacuated. Further reactivations took place in 1951 in connection with the ruinous flood that affected northeastern Italy. In 1935, the village of Alverà was included in the list of the towns to be relocated at the expense of the Italian government.

The mechanism of failure emerging from all these data is confirmed also by monitoring for about ten years, with continuous survey of the main hydrological and kinematic parameters. It was shown that the landslide is not strictly season-dependant, but tends to move round the year with accelerations induced by ordinary rainfall and snowmelt. This means that the remedial works should take into account not only the most critical situations but also the ordinary hydrological conditions.

\section{Causes}

The recurrent activity of the landslide after the retreat of the Würmian Glaciers seems to be related mainly to structural causes rather than the climate. Although climatic changes, both in the long and short terms (seasonal variations), have certainly induced an increase in the frequency and rate of movement, the continuous sliding activity seems to be connected with the extensive presence of clayey and marly formations in the lower part of the slopes. The most ancient reactivations seem nevertheless to be linked, directly or indirectly, with the presence of the thick Würmian glacial cover and melting of the permafrost.

\section{Geotechnical Investigations}

Because of favourable morphological conditions, the area of Cortina d'Ampezzo has witnessed progressive urban development, which has also been linked with intense tourism activities. Because of the intense urbanisation and the interest that this region holds for tourism, the presence of active landslides, even of slow movements, makes the area particularly vulnerable and subject to high geomorphological risk. In fact, according to Gasparetto et al. (1996), "the slow landslide can be hazardous in two ways. Firstly the gentle deformation may cause damage to structures on the slope and secondly the strength of the slope is gradually reduced by strain softening and the slope may fail in a catastrophic way".

Geotechnical laboratory tests were carried out on more than 40 samples from boreholes, drainage trenches, and trial pits. The results showed significant differences between the samples collected at any depth in the slope and those taken from the slip surface in a trial pit dug in the lower part of the Alverà Landslide.

Moreover, tests on cores from the boreholes permitted the distinction of two separate hydrogeological units. The upper one (with a maximum thickness of 20-25 m), within which the landslide occurred, consists of irregular, poorly sorted blocks of the original rock scattered in an argillaceous matrix and widely affected by joints. The lower unit consists of more consolidated homogeneous clays. A system of fissures filled with calcite (up to some centimetres thick) seems to indicate abundant water circulation from the upper calcareous slabs.

The monitoring system, installed in 1989 and improved in 1994, consists of inclinometers, piezometers (equipped with electric transducers for the measurement of hydraulic head in the slope), and steel-wire extensometers for the continuous measurement of landslide displacements. The data are recorded every ten minutes.

Altogether ten boreholes were drilled to depths ranging from $9 \mathrm{~m}$ to $30 \mathrm{~m}$. More recently, five more boreholes were added in order to detect the slip surface at different locations along the landslide body. All these boreholes were placed along a longitudinal profile and a cross-section of the landslide (see Fig. 2 for location). Other sixteen shallow boreholes were drilled between the above-mentioned boreholes for carrying out in situ permeability tests and detecting the water table. Furthermore, in 1992 a meteorological station was set up in order to record precipitation (rainfall and snow), air temperature, and snow cover thickness.

The trend of piezometric level indicates a water table very close to the ground surface and prone to extremely rapid fluctuations in accordance with rainfall and snowmelt (Fig. 3). Moreover, an analysis of the link between rainfall and groundwater level in some representative critical situations was carried out. For this purpose, twenty-seven cases were considered. A delay time of about five hours 


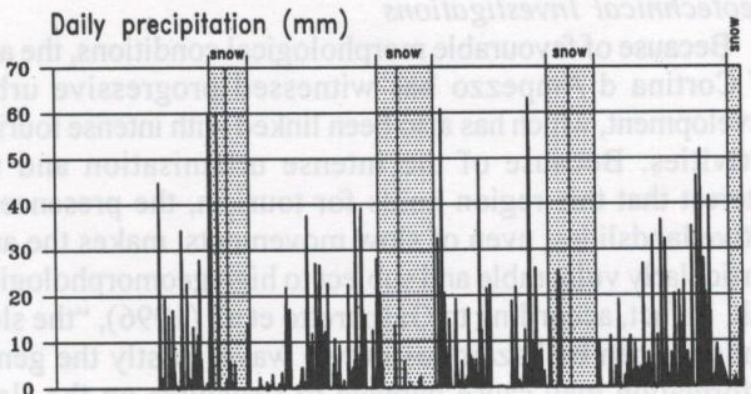

Groundwater level (m)

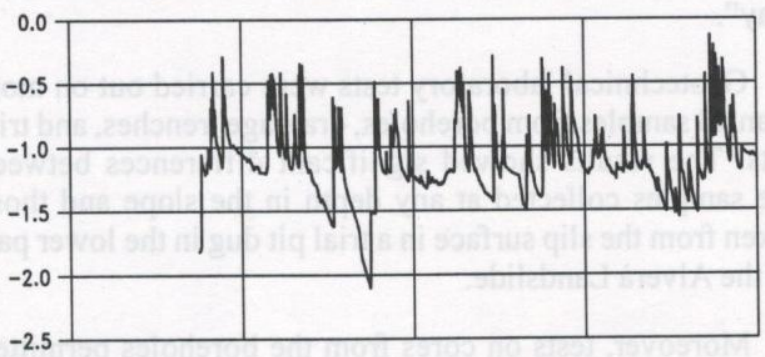

Displacements $(\mathrm{mm})$

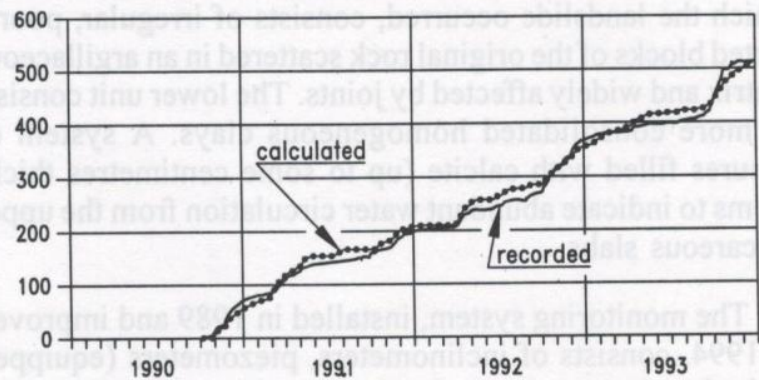

Fig. 3: Precipitation depth, groundwater level, recorded and calculated (by means of a visco-plastic rheological model) displacement in the Alverà Landslide.

was found between the beginning of rainfall and rising of groundwater level. The very rapid piezometric response of the aquifer to precipitation is probably due to infiltration through the more superficial sub-vertical tension cracks in the landslide body, which act as direct and short paths for the rainfall and surface runoff to the water table. Piezometers were also used for measuring the hydraulic conductivity of the soil. The values obtained are around $10^{-8} \mathrm{~m} / \mathrm{s}$. Apparently, these very low values do not correspond to the system of sub-vertical and spatially very close cracks present in the most superficial unit, but rather to the horizontal hydraulic conductivity of the clay matrix.

Each borehole is equipped with an inclinometer and an extensometer for the continuous measurement of displacements. A vast, more superficial, and very active landslide was detected in the toe area from the inclinometer measurements. It had a $5 \mathrm{~m}$ deep slip surface, showing displacements of $10 \mathrm{~cm}$ per year. Moreover, both analyses of recently drilled rock cores and inclinometer measurements have shown the existence of an $18 \mathrm{~m}$ to $25 \mathrm{~m}$ deep slip surface with the displacement rate of some centimetres per year.

A detailed topographical survey was carried out for measuring planimetric displacements, and for drawing a new reliable contour map and a large-scale longitudinal section of the landslide. Measurements were taken on thirty benchmarks, some of which were located close to the boreholes in order to compare the results with those of inclinometers and extensometers.

The above information was used for generating a numerical behavioural model (Fig. 3), which can accurately reproduce the ongoing instability processes (Angeli et al. $1996,1998)$. It is also able to forecast the magnitude of landslide movements in low-gradient clayey slopes, which are widespread in the Dolomites and many other mountain regions.

\section{The Tessina Landslide}

The Tessina Landslide (Plate 2) is a complex gravitational movement affecting the Tertiary Flysch Formation and is situated within the watershed of the Alpago (east of Belluno). In addition, in this case the particular urban

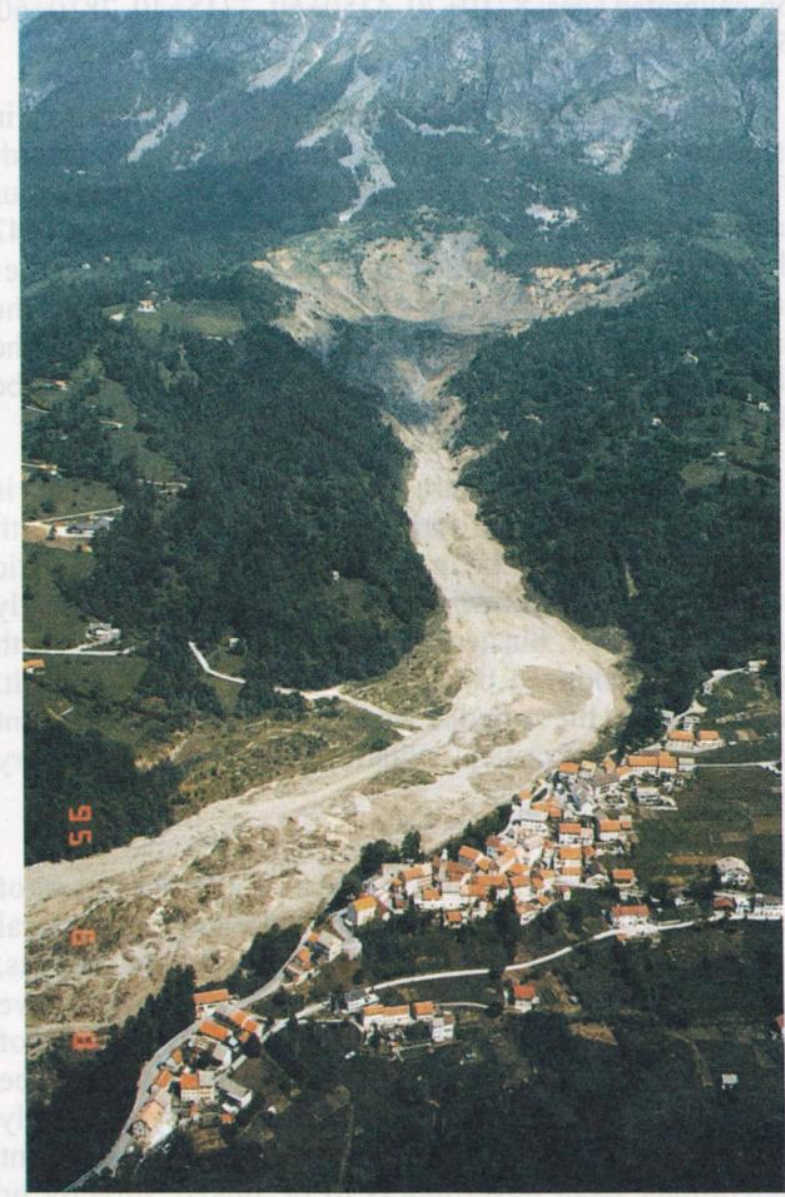

Plate 2: Aerial view of the Tessina Landslide with the threatened village of Funes. 
development of the area has required in-depth studies and installation of a monitoring system.

\section{Description and morphological details}

The Tessina Landslide (Fig. 1) is located on the southern slope of Mt. Teverone, in the eastern part of the Alpago Valley in the Province of Belluno (NE Italy). The slope affected by the landslide belongs to the northern flank of an asymmetrical brachy-syncline of the Alpago watershed (Mantovani et al. 1976). The material involved in the slope movement belongs to the Flysch Formation (Eocene). It is made up of a rhythmic interbedding of up to $1 \mathrm{~m}$ thick marlstones, clay shales, and calcarenite. This Formation is particularly permeable owing to a high density of fractures resulting mainly from tectonic stresses. It dips generally upstream, with overturned strata making up the main scarp and the upper landslide zone. Further downhill, the beds dip due south, towards the downstream with a low angle. The Quaternary deposits crop out continuously from the foot of the Mt. Teverone and cover with variable thickness the underlying formations. Apart from vast detrital covers found at the foot of Mt. Teverone, tills from the R. Piave Glacier and other local glaciers prevail.

The Tessina Landslide lies between the altitudes 1,200 $\mathrm{m}$ and $640 \mathrm{~m}$. It is classified as a complex movement including a rotational slide in its upper part and a flow in its mid-lower part. On the basis of morphological and dynamic characteristics, it has been divided into four units (Fig. 4): 1) the detachment zone (1,200-1,000 m), which consists of a highly fractured crown beyond the main scarp and the active scarp itself; 2) the upper accumulation zone (1,000-975 m), identified in a sub-horizontal embayment, $500 \mathrm{~m}$ wide and $350 \mathrm{~m}$ long, within which newly-collapsed material can be accumulated before being eventually transported onto a secondary scarp at an altitude of about $975 \mathrm{~m}$; 3) the transport zone (975-900 m), corresponding to the steep (about $30^{\circ}$ ) scarp immediately below the upper accumulation zone, which funnels landslide material with the highest speed into the main valley below; and 4) the lower accumulation zone (below $900 \mathrm{~m}$ ) in which the landslide material, re-deposited as a mudflow, fills the existing valley.

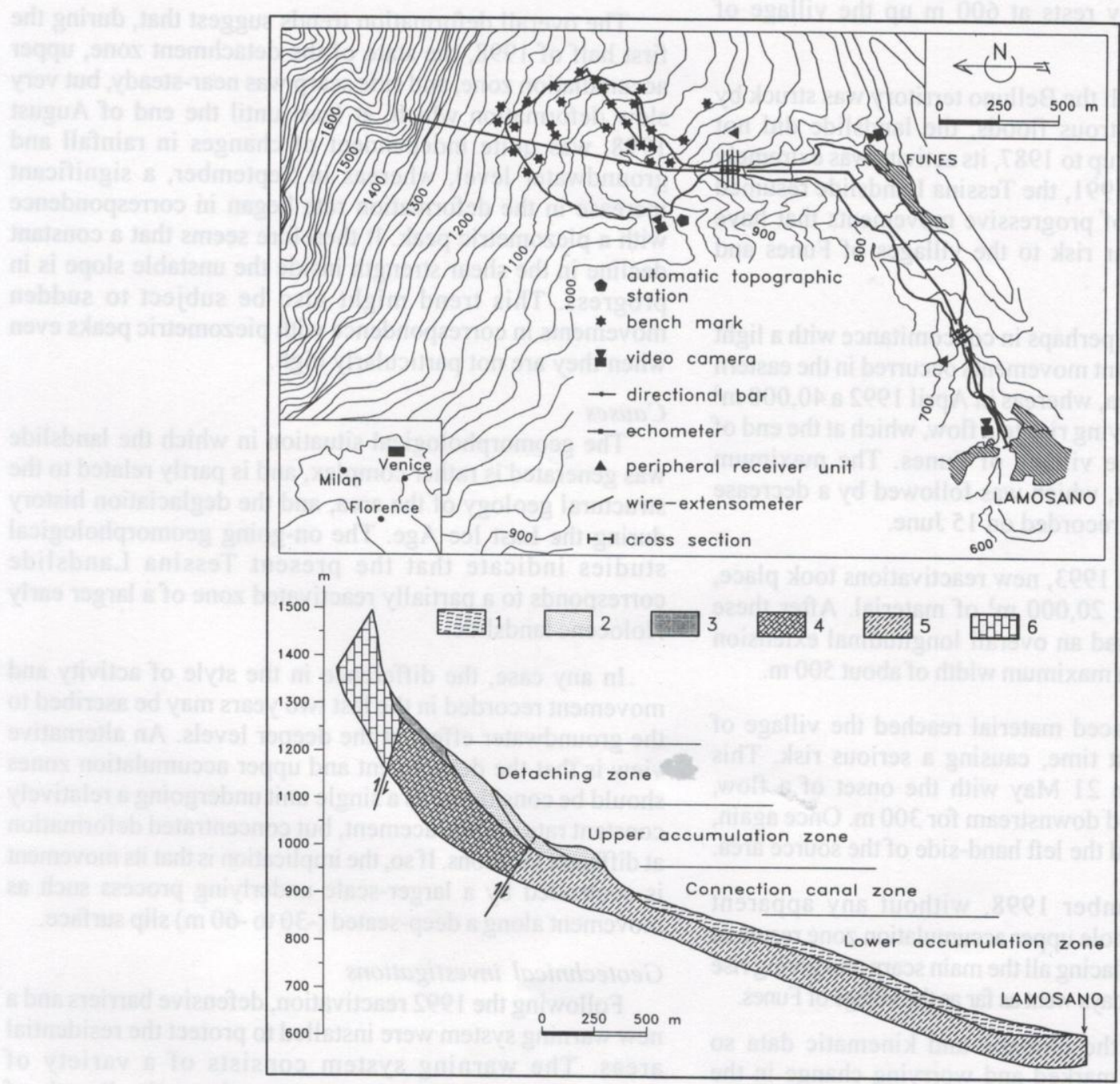

Fig. 4: Monitoring and warning system on the Tessina Landslide and longitudinal geological section showing the main morphological units. 
The latter extends for about $1.5 \mathrm{~km}$ between the altitudes of $900 \mathrm{~m}$ and $610 \mathrm{~m}$, and endangers the villages of Funes and Lamosano.

The landslide evolution is still in progress and has led to a constant widening of the source area, which from the original $300,000 \mathrm{~m}^{2}$ is now about $500,000 \mathrm{~m}^{2}$. The total displaceable volume has been estimated at 7 million $\mathrm{m}^{3}$. The velocity of the movement seems to vary considerably according to the episodes and sections considered. The maximum velocities ( 70 to $100 \mathrm{~m} /$ day) were recorded uphill of Lamosano in May 1992. During the same period, velocities of about 25 to $30 \mathrm{~m} /$ day were recorded in the proximity of Funes.

\section{Past events and style of activity}

The Tessina Landslide was triggered by the intense rainfall (398.7 mm just in the month of October) of 30 October 1960 as a rotational slide involving some $1,000,000 \mathrm{~m}^{3}$ of material. In the following four years, always after considerable precipitations, three reactivations took place, affecting the same material. They led to the formation of a flow, which eventually rests at $600 \mathrm{~m}$ up the village of Lamosano.

In 1966, although all the Belluno territory was struck by one of the most disastrous floods, the landslide did not move significantly, and up to 1987 , its activity was extremely reduced. In 1990 and 1991, the Tessina Landslide resumed its activity by means of progressive movements that have never caused particular risk to the villages of Funes and Lamosano.

In December 1991, perhaps in concomitance with a light seismic shock, significant movements occurred in the eastern sector of the source area, whereas in April 1992 a 40,000 m² wide area collapsed, giving rise to a flow, which at the end of the month reached the village of Funes. The maximum landslide advancement, which was followed by a decrease of the movement, was recorded on 15 June.

In July and August 1993, new reactivations took place, which mobilised some $20,000 \mathrm{~m}^{3}$ of material. After these events, the landslide had an overall longitudinal extension exceeding $2.5 \mathrm{~km}$ and a maximum width of about $500 \mathrm{~m}$.

In 1995, the displaced material reached the village of Lamosano for the first time, causing a serious risk. This reactivation started on 21 May with the onset of a flow, which in 10 days moved downstream for $300 \mathrm{~m}$. Once again, the detachment affected the left hand-side of the source area.

Finally, in September 1998, without any apparent triggering cause, the whole upper accumulation zone resumed its movement, thus displacing all the main scarp and giving rise to a flow which in a few days went as far as the village of Funes.

A comparison of the climatic and kinematic data so far recorded shows a marked and worrying change in the activity style and the evolution of the slope movement: observations carried out since 1960 suggest that prolonged periods of intense rainfall and/or snowmelt may be an important trigger for major reactivations of the Tessina Landslide. In mid-September 1998, however, all the basin material rapidly increased its motion (up to $10 \mathrm{~m}$ per week) in the upper accumulation zone, remaining constant for about ten days. This rapid movement declined in early October, and afterwards it continued with constant velocity until March 1999. These movements have caused the collapse of the frontal part of the accumulation zone and the retreat of the crown by some tens of metres, with consequent worsening of the stability conditions over the whole area.

The displacement data revealed two different deformational styles: during 1992-1998, and after the second half of 1998. During the last period, a slow and continuous movement of the entire unstable area has taken place (detachment zone, south-eastern scarp, and upper accumulation zone), whereas the movement had mainly affected the left flank of the detachment zone during the first period. The upper accumulation zone partially resumed its movement because of the overload resulting from the flows coming from the main scarp.

The overall deformation trends suggest that, during the first half of 1998, the state of the detachment zone, upper accumulation zone, and side scarp was near-steady, but very slow deformation which, at least until the end of August 1998, was quite independent of changes in rainfall and groundwater level, whereas in September, a significant increase in the deformation rate began in correspondence with a piezometric peak. It therefore seems that a constant decline in the shear strength inside the unstable slope is in progress. This trend might also be subject to sudden movements in correspondence with piezometric peaks even when they are not particularly high.

\section{Causes}

The geomorphological situation in which the landslide was generated is rather complex, and is partly related to the structural geology of the area, and the deglaciation history during the Last Ice Age. The on-going geomorphological studies indicate that the present Tessina Landslide corresponds to a partially reactivated zone of a larger early Holocene landslide.

In any case, the difference in the style of activity and movement recorded in the last two years may be ascribed to the groundwater effect at the deeper levels. An alternative view is that the detachment and upper accumulation zones should be considered as a single unit undergoing a relatively constant rate of displacement, but concentrated deformation at different locations. If so, the implication is that its movement is controlled by a larger-scale underlying process such as movement along a deep-seated $(-30$ to $-60 \mathrm{~m})$ slip surface.

\section{Geotechnical investigations}

Following the 1992 reactivation, defensive barriers and a new warning system were installed to protect the residential areas. The warning system consists of a variety of deformation and velocity sensors along the length of landslide, each automatically sending signals to a data centre in Lamosano, in turn linked with the fire station in Belluno. 
When deformation rates exceed a critical value, alarms are triggered automatically at key civil defence locations.

To accommodate the range of deformation styles encountered along the landslide (from rotational sliding of the scarp to the advance of distal mudflows); the sensor array incorporates electronic distance measuring (EDM) stations, directional bars, echometers, wire-extensometers, and video cameras (Fig. 4). As for the slow movements (typical for the detachment and upper accumulation zone) are concerned, displacements are monitored by (a) EDM stations measuring the positions of more than 30 benchmarks at 6-hourly intervals, and (b) two multiple-base wire extensometers ( 280 and $390 \mathrm{~m}$ long), capable of detecting millimetric movements; these short-term measuring stations are currently being integrated into a recently installed new baseline GPS network that allowed upper accumulation area to be zoned according to different rates of movement (Fig. 5). In the lower accumulation zone, where the landslide evolves into a mudflow, surface movement is monitored by two clusters of directional bars and echometers (Fig. 4), one at an altitude of about $920 \mathrm{~m}$ (across the junction between the transport zone and lower accumulation zone) and the other about $670 \mathrm{~m}$ (between Funes and Lamosano). The directional bars hang vertically from a cable across the valley with their lower ends resting on the mudflow. If they become tilted by surface movement more than $20^{\circ}$ from the vertical for over 20 seconds, an alarm signal is automatically triggered by closure of a mercury switch; the adjacent echometers, which constantly measure the surface elevation of the mudflow, are used to confirm alarms from the directional bars. Before arriving at Lamosano and Belluno, the raw measurements are pre-processed at one of the three peripheral receiving units, powered by photovoltaic panels, which are used not only to alert against possible hazards, but also to provide operators with almost uninterrupted reliability test of each recording instrument.

To mediate the triggering effect of rainfall, a drainage tunnel was dug in the upper part of the slope above the main scarp. For monitoring the local flow of groundwater, arrays of piezometers were installed within and around the tunnel, together with an adjacent meteorological station. As a result, since 1998 it has been possible to compare piezometric and meteorological data with variations in rates of movement across the EDM network in the upper accumulation zone. The objectives are to quantify any link between rainfall intensity and duration, variation in groundwater level, and rates of landslide reactivation. Preliminary results are reported by Mantovani et al. 2000 .

At present, the widening and simultaneous acquisition of the whole unstable area and the continuous removal of the landslide scarp have caused increasing risk to the inhabitants, in particular, to the village of Funes which, owing to the burial of the valley by a series of flows occurring since 1960, could easily be flooded by new events. In order to guarantee the safety of the population and activate the civil defence plan for the evacuation of the inhabited centre, the monitoring system was equipped with a real-time transmission system, so that all the agencies involved in the emergency plan may be immediately alerted. Furthermore, a forecasting model based on an existing cellular automata (CA) simulation for landslides (Program SCIDDICA) that had been partially verified against data for landslides in Japan is being experimented. Preliminary results from the Tessina simulation are in a good agreement with the observed landslide evolution, indicating that the CA may be an important forecasting tool (Avolio et al. in press).
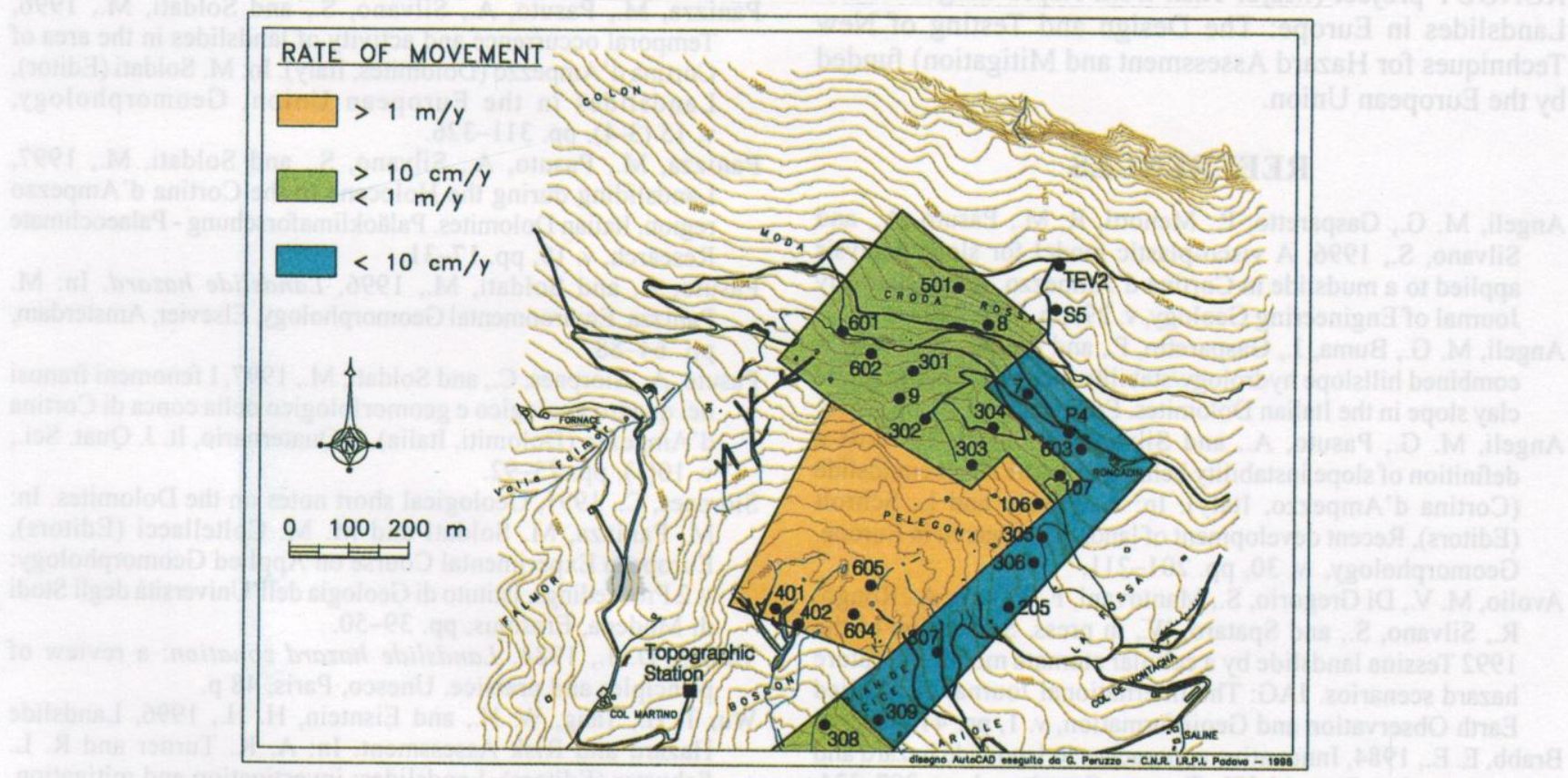

Fig. 5: Zonation of the upper accumulation area related to the 1998 recorded displacements. Location of the topographic benchmarks is also reported. 


\section{CONCLUSIONS}

The experience acquired on some landslides in densely populated areas has shown that it is particularly important to provide valuable and reliable landslide assessment data to the planners and decision-makers. They may further incorporate them in land planning policies, which have been quite limited so far. This could give a further contribution to invert the widespread tendency of many countries to face the landslide problem only in terms of post-event clearance and remedial measures instead of adequate prevention planning policies.

In order to assess landslide hazard correctly, it is necessary to carry out in-depth investigations on the spatial and temporal occurrence of mass movements in the study area. The approach to the study of landslides, according to the cases and scales of investigation, could benefit from various methodologies and techniques, such as geomorphological mapping, and geotechnical and hydrological investigations.

The case studies here discussed clearly show the important role of technical instrumentation as a means of investigation for better understanding the kinematics governing the movement. In this way, it might also be possible to forecast the landslide evolution by means of numerical models, and to mitigate its hazards by applying adequate control measures for the safety of human life and property.

\section{ACKNOWLEDGEMENTS}

These investigations were part of the research activities carried out by the authors within the framework of the RUNOUT project (Major Risk from Rapid Large-Volume Landslides in Europe: The Design and Testing of New Techniques for Hazard Assessment and Mitigation) funded by the European Union.

\section{REFERENCES}

Angeli, M. G., Gasparetto, P., Menotti, R. M., Pasuto, A., and Silvano, S., 1996, A visco-plastic model for slope analysis applied to a mudslide in Cortina d'Ampezzo, Italy. Quarterly Journal of Engineering Geology, v. 29, pp. 233-240.

Angeli, M. G., Buma, J., Gasparetto, P., and Pasuto, A., 1998, A combined hillslope hydrology/stability model for low-gradient clay slope in the Italian Dolomites. Eng. Geol., v. 49, pp. 1-13.

Angeli, M. G., Pasuto, A., and Silvano, S., 1999, Towards a definition of slope instability behaviour in the Alverà mudslide (Cortina d'Ampezzo, Italy). In: A. Pasuto and L. Schrott (Editors), Recent development of landslide research in Europe. Geomorphology, v. 30, pp. 201-211.

Avolio, M. V., Di Gregorio, S., Mantovani, F., Pasuto, A., Rongo, R., Silvano, S., and Spataro, W., in press, Simulation of the 1992 Tessina landslide by a cellular atomata model and future hazard scenarios. JAG: The International Journal of Applied Earth Observation and Geoinformation, v. 1, pp. 41-50.

Brabb, E. E., 1984, Innovative approaches to landslide hazard and risk mapping. Proc. 4th ISL, Toronto, Canada, v. 1, pp. 307-324.

Brunsden, D., 1984, Mudslide. In: D. Brunsden and D. B. Prior(Editors), Slope Instability, Wiley \& Sons, Chichester, pp. 363-418.
Carrara, A., Cardinali, M., Detti, R., Guzzetti, F., Pasqui, V., and Reichenbach, P., 1991, GIS techniques and statistical models in evaluating landslide hazard. Earth Surface Proc. and Landforms, v. 16 (5), pp. 427-445.

Carrara, A. and Guzzetti, F. (Editors), 1995, Geographical Information Systems in Assessing Natural Hazards. Kluwer Academic Publishers, Dordrecht, The Netherlands, $353 \mathrm{p}$.

Gasparetto, P., Mosselmann, M., and Van Ash, T. W. J., 1996, The mobility of the Alverà landslide (Cortina d'Ampezzo, Italy). In: M. Soldati (Editor), Landslides in the European Union, Geomorphology, v. 15 (3-4), pp. 327-335.

Hansen, A., 1984, Landslide Hazard Analysis. In: D. Brunsden and D. B. Prior (Editors), Slope Instability, Wiley \& Sons, Chichester, pp. 523-602.

Hartlén, J. and Viberg, L., 1988, General report: Evaluation of landslide hazard. In: C. Bonnard (Editor), Landslides. Proc. 5th ISL, Lausanne, Balkema, Rotterdam, v. 2, pp. 1037-1057.

Hutchinson, J. N., 1995, Keynote paper: Landslide hazard assessment. In: D. H. Bell (Editor), Landslides. Proc. 6th ISL, Christchurch (NZ), Balkema, Rotterdam, v. 3, pp. 1805-1841.

Jones, D. K. C., 1992, Landslide hazard assessment in the context of development. In: G. J. H. McCall, D. J. C. Laming and S. C. Scott (Editors), Geohazards, Chapman \& Hall, London, pp. 117-141.

Kienholz, H., 1984, Landslide hazard assessment for landslide hazard zonation. In: J.-C. Flageollet (Editor), Mouvements de terrains, Actes Colloque de Caen, Doc. BRGM, v. 83, pp. 317-325.

Mantovani, F., Panizza, M., Semenza, E. and Piacente S., 1976, L'Alpago (Prealpi Bellunesi). Geologia, geomorfologia e nivopluviometria. Boll. Soc. Geol. It., v. 95, pp. 1589-1656.

Mantovani, F., Pasuto, A., Silvano, S., and Zanoni, A., 2000, Data collection aiming at the definition of future hazard scenarios of the Tessina Landslide. JAG, The International Journal of Applied Earth Observation and Geoinformation, v. 1, pp. 33-40.

Meijerink, A. M. J., 1988, Data acquisition and data capture through terrain mapping units. ITC Journal, v. 1, pp. 23-44.

Panizza, M., 1987, Geomorphological hazard assessment and the analysis of geomorphological risk. In: V. Gardiner (Editor), International Geomorphology 1986 Part I, John Wiley \& Sons, Chichester, pp. 225-229.

Panizza, M., Pasuto, A., Silvano, S., and Soldati, M., 1996, Temporal occurrence and activity of landslides in the area of Cortina d'Ampezzo (Dolomites, Italy). In: M. Soldati (Editor), Landslides in the European Union, Geomorphology, v. $15(3-4)$, pp. 311-326.

Panizza, M., Pasuto, A., Silvano, S., and Soldati, M., 1997, Landsliding during the Holocene in the Cortina d'Ampezzo region, Italian Dolomites. Paläoklimaforschung - Palaeoclimate Research, v. 19, pp. 17-31.

Pasuto, A. and Soldati, M., 1996, Landslide hazard. In: M. Panizza, Environmental Geomorphology, Elsevier, Amsterdam, pp. 64-88.

Pasuto, A., Siorpaes, C., and Soldati, M., 1997, I fenomeni franosi nel quadro geologico e geomorfologico della conca di Cortina d'Ampezzo (Dolomiti, Italia). Il Quaternario, It. J. Quat. Sci., v. $10(1)$, pp. $75-92$.

Siorpaes, C., 1991, Geological short notes on the Dolomites. In: M. Panizza, M. Soldati and M. M. Coltellacci (Editors), European Experimental Course on Applied Geomorphology: v. 2 Proceedings, Istituto di Geologia dell'Università degli Studi di Modena, Erasmus, pp. 39-50.

Varnes, D. J., 1984, Landslide hazard zonation: a review of principles and practice. Unesco, Paris, $48 \mathrm{p}$.

Wu, T. H., Tang, W. H., and Eisntein, H. H., 1996, Landslide Hazard and Risk Assessment. In: A. K. Turner and R. L. Schuster (Editors), Landslides: investigation and mitigation, Special Report, Transportation Research Board, National Research Council, v. 247, pp. 106-118. 